\title{
Evaluation of Family Planning Programs in Minahasa Regency
}

\author{
Abdul Rahman Dilapanga* \\ State Administration Study Program \\ Faculty of Social Science \\ Manado State University \\ Manado, Indonesia \\ abdulrahmandilapanga@unima.ac.id
}

\author{
Jeane Mantiri \\ State Administration Study Program \\ Faculty of Social Sciences \\ Universitas Negeri Manado \\ Manado, Indonesia \\ jeanelitha@unima.ac.id
}

\begin{abstract}
The problem in this research is the Evaluation of Family Planning Programs in Minahasa Regency. The Family Planning Program is a national development program in the field of the population that contributes to the control of population growth through birth control and restrictions as well as improving the welfare of the community, in order to realize and improve the quality of Indonesia's human resources. This study was designed with a qualitative approach with a focus of research using the CIPP evaluation model (context, input, process, product).The results of this study conclude: a Context Evaluation of Family Planning Program in Minahasa Regency describes various needs that support program activities, program objectives and priorities, strengths and weaknesses of the program as well as environmental support, especially community support in the form of community participation in family planning program activities. $b$. Input Evaluation; focused on the availability of resource support which includes budget support, facilities and infrastructure and human resources that support the implementation of family planning programs. c. Process Evaluation, focused on the mechanism and time of activity implementation, the use of facilities and infrastructure to support the program and standard operating procedures (SOP) of the KB program, as well as the activity reporting system. d. Product Evaluation, the evaluation results show that the family planning program implemented by the BKBP3A of the Minahasa Regency has directed the objectives of the family planning program.
\end{abstract}

Keywords: Evaluation, Program, Family, Planning

\section{INTRODUCTION}

In the development process, various problems often arise due to development imbalances, such as; population, education, health, unemployment, crime, human trafficking, violations of the order, social and economic inequality, and social ills and so on[1]. These disparities are a challenge that continues to be faced by the government in the effort to realize the fundamental rights of citizens, in order to realize the goals of national development is to realize a just and prosperous society based on Pancasila and the 1945 Constitution[2].Indonesia, as a developing country, is actively implementing development in various fields, including building a prosperous and happy family. Population issues facing Indonesia today include: 1) population quantity problems, 2) population quality problems, 3) population mobility problems, 4) population data collection and administration problems[3].

One of the policies promoted by the government in controlling the quantity and quality of population in Indonesia is through the Family Planning (KB) program. The Family Planning Program is one of the national development programs that has a positive contribution and plays an important role in realizing Indonesia's human resources. The Government of the Minahasa Regency as one of the autonomous regions in North Sulawesi Province, strongly supports the implementation of national development that has been determined by the Central Government in the field of Family Planning with the vision of "balanced population in 2015" with the mission of "realizing development that is insightful of the population and creating a happy and small family prosperous". In Government Regulation No: 38 of 2007, it is stressed that government affairs in the field of family planning are mandatory matters that must be carried out by local governments, because these government affairs need to be regulated through local government policies in accordance with established norms, standards, procedures and criteria[3].

The Government of the Minahasa District has established a Regents Regulations on: Main Tasks, Functions and Duties of the Family Planning Agency, Women's Empowerment and Child Protection (BKBP3A), one of the main tasks of which is evaluating the planning and implementation of regional policies in the field of Family Planning. The implementation of the Indonesian Family Planning Program has been carried out since the beginning of the New Order government until now, but the analysis of the evaluation of the family planning program has not received much attention. The problems in this study were formulated in the form of research questions: How is the evaluation of the Family Planning Program in Minahasa Regency?. 


\section{RESEARCH METHODS}

The method or approach used in this study is a qualitative approach, in accordance with the formulation of the problem and research objectives which aim to uncover, analyze and interpret field data, therefore a qualitative approach is used. This study focuses on the process of description and giving meaning to various factors related to the Family Planning Program Evaluation, therefore this study uses a qualitative approach. The focus in qualitative research is closely related to the problems that are formulated and used as a reference in determining the focus of research. In this study the main focus is "Family Planning Program Evaluation. This research takes place in Minahasa Regency, more specifically in the Family Planning, Women's Empowerment and Child Protection Agency (BKBP3A) District of Minahasa.

In naturalistic research the sample is only a source that can provide information. Samples can be things, events, people, situations that are observed [4]. Furthermore Lofland and Lofland, stated "the main data sources in qualitative research are words, and the rest of the action is additional data such as documents and others"[5]. In accordance with the problem and focus in this study, the data sources are: Key informants, initial or key informants in this study were selected purposively (Stratified Purposive Sampling).

Whereas the informant is then asked to the initial informant to appoint another person who can really provide information and then this informant is also asked to appoint another informant and so on which is commonly called "snowball sampling", carried out sequentially or serially. In this study, which was seen as the initial informant or key informant was the Head of BKBP3A of the Minahasa Regency. In qualitative research, the main instrument is the researcher himself. Nasution, stated "at the beginning of the study research the only tool"[4].

To facilitate the collection of data, the researchers used tools such as interview guides, field notes, tape recorders, photo cameras and so on. In qualitative research, the process of collecting data moves from the empirical field in an effort to build theory from data. The data collection process in this study was conducted from March to May 2016, which included three stages, namely: a) The Process of Entering the Research Site (Getting In). Before entering the research location, preparations are made in the form of interview guidelines, research permits and other supporting tools. b). When Being at the Research Location (Getting Along), when and while at the research location, then as a researcher seeks to introduce themselves, mambur and establish a good relationship with all parties at the research location, so that there is a harmonious relationship with them. c). Collecting data (Logging the data), during the process of data collection researchers have tried to listen, observe and record all the things that were heard and seen, then categorized according to patterns, themes and research focus.

In qualitative research, data analysis is conducted from the beginning and the research process takes place.
Data analysis used interactive analysis models from Miles and Huberman, namely: Data Reduction, Data Presentation and Verification [6]. For the validity of the data used four criteria tests proposed by Moleong, namely: a) degree of trust, b) dependability, c) dependability, d) certainty [5].

\section{RESEARCH RESULTS AND DISCUSSION}

\section{Context Evaluation}

Strengths in the implementation of family planning programs in the Minahasa Regency are community participation, support from the Minahasa District Government and the North Sulawesi Provincial Government. Various programs and activities carried out by the Minahasa District BKBP3A together with the community to support the successful implementation of the Family Planning Program in Minahasa Regency. Various BKBP3A Minahasa District activities carried out by the community in particular that can support the success of the KB program are: Toddler Family Development (BKB), Youth Family Development (BKR), Elderly Family Development (BKL), Family Environment Development (BLK) and contraception installation services. and Prosperous Family Income Improvement Efforts (UPPKS).

The results of the study above indicate the existence of community involvement or empowerment carried out by the government in this case BKBP3A Minahasa Regency. Empowerment itself is a process in which people or communities are involved in the implementation of family planning programs activities so that they gain knowledge, skills and foster a desire to overcome the various problems they face and take appropriate action.

The implementation of family planning programs through involving local communities through Posyandu activities, the community is given the freedom to determine the time and place of the implementation of activities. The results of interviews with Posyandu cadres also revealed that in carrying out activities, the Posyandu was supported by complete facilities in the form of scales, posyandu register books, posyandu signboards, cooking utensils and operational needs. Posyandu cadres involved in previous activities have received training, and refreshment so that posyandu cadres truly understand their responsibilities, duties and functions as cadres. This cadre training and training is seen as something urgent, because Posyandu Cadre training can be used as a vehicle that can bridge the needs of the program and the process of making the community independent in carrying out activities. The most important thing in community empowerment is how to make the community dynamic and positioned as an actor who plays an active role in various development activities.

\section{Input Evaluation}

In policy studies, the evaluation of inputs is intended to link the objectives, context, inputs, processes and products (results) of the program. Input evaluation in this study focused on the availability of program resources related to the availability of budget, personal (HR), and facilities and infrastructure used to support the achievement of program objectives.

To support family planning services in the Minahasa District BKBP3A, in 2015 and 2016 there were 
65 Health Facilities Integrated KB Services and planned in 2017 to become 97 health facilities. Supported by 156 HR of PKB / PLKB and 270 PPKBD spread across 270 villages and sub-districts, while in 2016 there were 1182 SubPPKBD, planned for 2017 to be 1242 people.

Human resource support is crucial to the success of family planning programs, with the support of PKB / PLKB, PPKBD and Sub PPKBD as the spearheads that play a role in the implementation of family planning programs at the district, sub-district, village and village levels, even to mobilize and socialize the program to the people directly. Real support of human resources (KB officers) in the field in terms of mobilizing activities, management and implementation to the data collection of each activity carried out. The BKKBN provides guidance that PKB has six main tasks and functions: planning, organizing, implementing, developing, reporting, and evaluating the National KB Program and other development programs in the target area.

In addition to human resource support, the success of the implementation of the family planning program is also inseparable from the financial support and facilities and infrastructure to support operational activities. Funding support for family planning programs sourced from the 2016 Minahasa district budget, for family planning programs Rp.38,105,000 and KB facility maintenance Rp. 243,000 . In addition, there is also a KB Operational Special Allocation Fund (DAK) of Rp. 801,820,000,.

While the support for family planning facilities and infrastructure in the Minahasa District BKBP3A is in the form:

1) The facilities for the KB service include: Obgyn Bed 6 units, IUD KIT 15 units, Implant KIT 15 units, Pick-up Inter-vehicle Pick-up Acceptor 1 unit, KB Car Service Unit (MUYAN).

2) KB Counseling Infrastructure Facilities include: 2 units of KB Information Car, Data Processing Equipment at the Counseling Center in the form of: Personal Computers 2 units, Note Book / Laptop 44 units, KIE KIT 16 units, KB Counseling Center 12 units, KIT Genre 1 unit, 54 units of motorbikes.

\section{Process Evaluation}

Process evaluation is carried out to understand the extent to which a program or activity has been carried out in accordance with a predetermined plan, so that the process evaluation always questions: "what program or activity is carried out, who carries out or who is responsible for the program, the start time and completion of an activity" One of the informants in his position as BKBP3A staff in Minahasa Regency explained: "The evaluation of the KB program process in Minahasa Regency was carried out with new target acceptors targeted by the central BKKBN then compared to the activities contained in the budget implementation document". To improve the performance of the BKBP3A in the Minahasa Regency in the field of family planning programs, a KB operational network was developed from the district, sub-district to village and subdistrict, RW and RT. Community institutions such as the $\mathrm{KB}$ Post, as the BKBP3A partner and network in implementing the $\mathrm{KB}$ program, the $\mathrm{KB}$ sub-post and the acceptor group play an important role and are strong in supporting the implementation of the KB program, because the KB Post and KB sub-post have high fighting power and are spread in all villages / sub-districts up to RW and RT.

Process evaluation can be used as a source of information to explain product evaluation results. The results of observations and documentation studies conducted show that the implementation of family planning programs in Minahasa Regency has been carried out according to plan, both in terms of activity schedules, program implementers, funding and support for the availability of facilities and infrastructure such as $\mathrm{KB}$ lighting cars.

\section{Product Evaluation}

BKBP3A Minahasa Regency routinely evaluates family planning programs by involving Family Planning Field Officers (PLKB), Village Activists (TPD) and BKBP3A structural officials related to family planning programs such as the Women's Empowerment Field, Community Empowerment Field. In an interview with one of the informants explained that "the evaluation of the results was carried out 11 (eleven) times and once was done through the Minahasa District BKBP3A coordination meeting". In addition, meetings were also held with SubPPKBD (Village Family Planning Assistance Officials) in each village and kelurahan conducted at the end of each activity, namely once a month, in addition to the results of achievements outlined in quarterly and annual reports.

Family planning service activities and contraception tools for infertile couples are directed at fostering the sustainability of family planning participants and achieving new participants. Data from the Field of Family Planning, BKBP3A of the Minahasa Regency, that until March 2016, the number of fertile age couples (PUS) in the Minahasa Regency amounted to 76,961, with the number of active family planning participants 69,898 $(90.82 \%)$, with the distribution of contraceptive use as follows: IUD (9.24\%), MOW (0.55\%), MOP (0.09\%), CONDOM (1.61\%), IMPLANT (19.05\%), SUNTIK (40.66\%), and PIL (28.80\%).

Activities to provide family planning services and contraceptives for poor families are conducted free of charge, while the community / family can be directed to attend family planning independently. Provision of family planning services is expected to be able to break the cycle of poverty, in this case the less capable acceptors are given subsidized contraceptive devices free of charge. With the free family planning program, it is expected that families who were poor can plan their family's future without having to be shackled by the economic difficulties of the family.

Based on evaluation data obtained at the BKBP3A of the Minahasa Regency, there are 270 BKB family planning programs related to Toddler Family Development in 2015 and 2016, then in 2017 it is predicted to be $310 \mathrm{BKB}$ groups. Bina KeluargaRemja (BKR) in 2015 formed 65 groups, in 2016 there were 71 groups and in 2017 it is predicted to be 90 BKR groups. Whereas the Elderly Family Development (BKL) group in 2015 had formed $52 \mathrm{BKL}$ groups, in 2016 it increased to $98 \mathrm{BKL}$ 
groups and in 2017 it is predicted to increase to $131 \mathrm{BKL}$ groups.

\section{CONCLUSIONS AND RECOMMENDATIONS}

\section{Conclusion}

Based on the results of the analysis and discussion of the evaluation of family planning programs in the Minahasa Regency which is focused on a series of evaluations using the CIPP model approach, namely: Contex, Input, Process, Product, the following conclusions can be drawn:

1) Evaluation of Context of Family Planning Program in Minahasa Regency describes various needs that support program activities, program objectives and priorities, strengths and weaknesses of the program as well as environmental support, especially community support in the form of community participation in family planning program activities. The evaluation results show that the family planning program activities carried out by BKBP3A in Minahasa Regency is an increase in the participation of community-based family planning for fertile age couples (PUS) through the installation of contraceptives ". Successful implementation of family planning programs is highly dependent on community participation.

2) Input Evaluation; focused on the availability of resource support which includes budget support, facilities and infrastructure and human resources that support family planning programs can be implemented. Human resource support in this study was found not only to be limited to personnel possessed by the Minahasa District BKBP3A with employee status, but community support and participation as Posyandu, PPKBD and Sub PPKBD cadres. Another strength is the existence of financial support sourced from the Minahasa Regency APBD and the KB Program Special Allocation Fund (DAK).

3) Process Evaluation, focused on the mechanism and time of activity implementation, the use of facilities and infrastructure to support the program and standard operating procedures (SOP) of the $\mathrm{KB}$ program, and the activity reporting system. The results of the data analysis of interviews, observations and documentation studies conducted showed that the implementation of family planning programs in Minahasa Regency was carried out according to plan, both in terms of activity schedules, program implementers, funding and support for the availability of facilities and infrastructure such as $\mathrm{KB}$ lighting cars.

4) Product Evaluation, the evaluation results show that the family planning program implemented by the BKBP3A of the Minahasa Regency has been directed towards the purpose of the family planning program, namely establishing a prosperous small family according to the socio-economic strength of the family through birth control and regulation. The realization of the results of the implementation of the $\mathrm{KB}$ program can also be seen from various activities through the Family Development Toddler (BKB), Family Remana Development (BKR), Elderly Family
Development (BKL) and Efforts to Increase Welfare Family Income (UPPKS).

2. Recommendations

1) To evaluate the performance of the BKBP3A in the Minahasa Regency in the years with the CIPP model which includes four sets of activities namely context evaluation, input evaluation, process evaluation, and product evaluation.

2) To ensure the evaluation process carried out with this CIPP model, it is necessary to develop a standard operating procedure (SOP).

3) Program evaluators need training and development of measurement tools or indicators of program achievement.

4) Funding support, is still relatively small compared to the operational area of BKBP3A in Minahasa Regency and therefore needs more adequate funding support through the APBD in the coming years.

\section{ACKNOWLEDGMENT}

The author would like to express his gratitude to the Heads of Social Science Faculty, Unima for providing the funding, so this research could be completed.

\section{REFERENCES}

[1] J. Mantiri, A. R. Dilapanga, and C. Mongi, "Evaluating the Management of Administrative Information Systems at the Tomohon City Population and Civil Registry Office," J. Kaji. Policy. and Science Adm. Country (JOURNAL Adm., 2020.

[2] UUD 45, "RI's 1945 Constitution," Dep. Healthy. RI, 1945 .

[3] PRepublic of Indonesia resident, "Government Regulation of the Republic of Indonesia Number 38 Year 2007 Concerning the Division of Government Affairs between the Government, Provincial Governments, and Regency / City Governments," Menkumham RI, 2007.

[4] Z. Azmi, A. A. Nasution, and W. Wardayani, "Understanding Qualitative Research in Accounting," Accountability, 2018.

[5] L. J. Moleong, Qualitative Research Methodology (Revised Edition). 2017.

[6] M. B. Miles and M. A. Huberman, Qualitative Data Analysis: A Resource Book About New Methods. 2012.

[7] M. B. Miles and M. A. Huberman, Qualitative Data Analysis: A Resource Book About New Methods. 2012. 